ks. dr hab. Dariusz Lipiec ${ }^{1}$

ORCID: 0000-0002-8890-2062; dlipiec@kul.pl

Katolicki Uniwersytet Lubelski Jana Pawła II

\title{
Budowanie wspólnoty parafialnej z osobami z niepełną sprawnością
}

\section{Streszczenie}

Parafia jest wspólnotą wiary, kultu i miłości braterskiej. W jej budowaniu biorą udział osoby z niepełną sprawnością. Słuchają one słowa Bożego i głoszą je w różnoraki, dostępny dla nich sposób. Uczestniczą one w liturgii, przystępują do sakramentów świętych i są adresatami modlitwy innych parafian. Jednocześnie czynnie uczestniczą w liturgii i nabożeństwach oraz swoje modlitwy i cierpienie ofiarowują za innych ludzi. Uczestnicząc w budowaniu parafii-wspólnoty braterskiej starają się realizować swoje posłannictwo w Kościele i świecie, apostołując poprzez ukazywanie innym chrześcijańskiego stylu życia. Osoby z niepełną sprawnością angażują się w działalność charytatywną parafii, a także $\mathrm{w}$ zrzeszenia religijne istniejące na jej terenie. Słowa kluczowe: niepełnosprawność, parafia, wspólnota, apostolstwo

\section{Abstract}

\section{Building a Parish Community with People with Disabilities}

Parish is a community of faith, of cult and of brotherly love. People with disabilities participate in creating this community. They listen to God's word and they preach it in various possible ways. They participate in the liturgy, they receive holy sacraments and they are prayed for by all the parishioners. At the same time, they actively participate in the liturgy and in other devotions, offering up their prayers and their suffering for other people. Participating in building the brotherly parish community, they try to implement their vocation in the Church and in the world, being the apostles of the Christian way of life. People with disabilities get engaged into the charity work of the parish as well as into the activity of the religious associations in their parish.

Keywords: disability, parish, community, apostolate

1 Ks. Dariusz Lipiec - prof. KUL, pracownik Katedry Teologii Pastoralnej na Wydziale Teologii Katolickiego Uniwersytetu Lubelskiego Jana Pawła II. 
Pojęcie wspólnoty jest obecne w naukach teologicznych i pozateologicznych. W naukach społecznych wspólnota jest rozumiana jako

zbiorowość lub grupa społeczna o silnej więzi wewnętrznej, zorganizowanym systemie relacji między jednostkami, charakteryzująca się wysokim stopniem identyfikacji oraz zaangażowania emocjonalnego członków; płaszczyznę przynależności stanowi akceptacja wartości i celów wspólnotowych, dominujących nad osobistymi interesami jednostek; powiązana ze środowiskiem geograficznym, przestrzennym i kulturowym ${ }^{2}$.

We wspólnocie odbywa się proces uspołeczniania jednostki, czyli socjalizacji, polegający na uczeniu się przez jednostkę ról społecznych, form życia wspólnotowego, kultywowania obyczajów i tradycji. Tam odbywa się zaspokajanie potrzeb obiektywnych i subiektywnych jednostki. Proces socjalizacji zmierza także ku ukształtowaniu w jednostce dążenia do realizacji dobra wspólnego. Zwraca się uwagę na dobrowolny charakter zaangażowanych w tworzenie wspólnoty, wynikający ze społecznej natury człowieka ${ }^{3}$.

W naukach teologicznych

wspólnota oznacza zjednoczenie osób oparte na autentycznych i głębokich relacjach międzyosobowych; [...] prawzorem i wezwaniem do budowania wspólnoty ludzi z Bogiem i między sobą jest doskonała jedność Trójcy Świętej i Jej odwieczny zamysł zbawienia człowieka we wspólnocie Ludu Bożego; wspólnotowy charakter zbawienia ustanowiony przez samego Boga wskazuje, że żadna relacja człowieka do Jezusa Chrystusa nie dokonuje się wyłącznie w ramach indywidualnej historii odizolowanych od siebie jednostek, lecz we wspólnocie całej ludzkości i w służbie dla niej; człowiek afirmowany ze względu na niego samego oraz traktowany przez Boga jako niepowtarzalna jednostka i partner zbawczego dialogu osiąga swoje ostateczne spełnienie jedynie na drodze osobowej przynależności do Kościoła jako wspólnoty wiary w zjednoczeniu z Trójcą Świętą i solidarności z innymi, zwłaszcza ubogimi, chorymi i skrzywdzonymi ${ }^{4}$.

2 L. Cynarzewska-Wlaźlik, Wspólnota. W naukach społecznych, w: Encyklopedia katolicka, t. 20, red. E. Gigilewicz, Lublin 2014, kol. 1001-1002.

L. Cynarzewska-Wlaźlik, Wspólnota. W naukach społecznych, dz. cyt., kol. 1002.

4 A. Nadbrzeżny, Wspólnota. W teologii, w: Encyklopedia katolicka, t. 20, dz. cyt., kol. 1000-1001. 
Tak rozumiana wspólnota jest wspólnotą zbawienia, bo chociaż oparta na społecznej naturze człowieka zmierza do pełnego zjednoczenia z Bogiem w przez Chrystusa w Duchu Świętym. Powołani do jej budowania są wszyscy wierzący, także ludzie „słabi”, a w ich liczbie dotknięci niepełną sprawnością, ponieważ są osobami ludzkimi, cieszącymi się podmiotowością, powołanymi do współpracy z Bogiem i innymi ludźmi w dziele zbawczym ${ }^{5}$.

Pierwszoplanowym miejscem, w którym osoby sprawne i obarczone niepełną sprawnością budują wspólnotę jest parafia. Parafia jest „określoną wspólnotą wiernych, utworzoną na sposób stały w Kościele partykularnym, nad którym pasterską pieczę, pod władzą biskupa diecezjalnego, powierza się proboszczowi jako jej własnemu pasterzowi"6. Jest ona podstawowym miejscem głoszenia słowa Bożego, sprawowania sakramentów i realizacji miłości chrześcijańskiej. Z tego powodu parafia jest nazywana wspólnotą wiary, kultu i miłości braterskiej ${ }^{7}$ W niej wierzący mogą doświadczać wspólnotowości Kościoła, dzięki czemu jest ona pierwszoplanowym miejscem realizacji powołania i posłannictwa chrześcijańskiego.

\section{Budowanie parafii-wspólnoty wiary}

Budowanie wspólnoty wiary dokonuje się przez głoszenie i słuchanie słowa Bożego ${ }^{8}$. Osoby z niepełną sprawnością są w parafii zarówno adresatami, jak i podmiotami przepowiadania Dobrej Nowiny. Głoszenie słowa Bożego ludziom z ograniczoną sprawnością jest trudniejsze niż taka działalność wobec osób sprawnych. Wynika to ze skutków niepełnosprawności, a zwłaszcza z ograniczeń, jakie ona powoduje. Komplikacje w przepowiadaniu Słowa do osób z niepełną sprawnością wynikają także z rodzaju obciążenia, jakim są dotknięci, i jej stopnia. Na sposób

\footnotetext{
5 Por. A. Bartoszek, Niepełnosprawność osób jako wyzwanie moralne, w: Osoby niepełnosprawne w życiu społeczeństwa i Kościoła, red. A. Bartoszek, D. Sitko, Tarnów 2003, s. 73-80.

6 KPK, kan. 515 § 1.

7 R. Kamiński, Duszpasterstwo w społeczeństwie pluralistycznym, Lublin 1997, s. 67-83.

8 R. Kamiński, Działalność zbawcza Kościoła w teorii i praktyce pastoralnej, Lublin 2007, s. $145-149$.
} 
przepowiadania wpływa również wiek i stan życia chrześcijańskiego osób z niepełną sprawnością: innego rodzaju głoszenia wymagają dzieci, młodzież i dorośli, inaczej przepowiada się słowo Boże osobom samotnym i żyjącym w rodzinie.

Specyfika przepowiadania do osób z niepełną sprawnością dotyczy w pierwszej kolejności treści wiary. Dla wielu takich osób trudnością jest pogodzenie prawdy o dobroci Boga $\mathrm{z}$ faktem wystąpienia $\mathrm{u}$ nich zjawiska niepełnosprawności. Z tego powodu na wspólnocie parafialnej, a zwłaszcza na duszpasterzach spoczywa konieczność wyjaśnienia takiego stanu rzeczy. Potrzebna jest w takiej sytuacji znajomość specyfiki niepełnosprawności, a przede wszystkim jej etiologii oraz przyczyn jej zaistnienia u konkretnych osób. Zadaniem duszpasterzy, ale także innych członków wspólnoty parafialnej, jest pomoc w odkryciu osobistego powołania tych ludzi w ramach powołania chrześcijańskiego. Osoby wspierające ludzi z niepełną sprawnością mają także za zadanie pomóc im w akceptacji ich sytuacji egzystencjalnej, gdy leczenie lub inny rodzaj terapii nie jest nieskuteczny w poprawie ich kondycji fizycznej i psychicznej. Akceptacja taka nie polega na „pogodzeniu się z losem", lecz na takim uznaniu aktualnej sytuacji, która zmierza do podjęcia podmiotowej, twórczej aktywności w świecie i Kościele, zwłaszcza we wspólnocie parafialnej.

Podobnie, jak osoby sprawne, ludzie z niepełną sprawnością ulegają procesom laicyzacyjnym. Są one wystawione na ich działanie jak inni członkowie społeczeństwa. Laicyzacja osób z niepełną sprawnością ma także swoją specyfikę, wynikającą z zaistniałego obciążenia. U części takich osób ukształtowała się mentalność materialistyczna, będąca efektem rekompensowania wartościami materialnymi ubytków w kondycji fizycznej lub psychicznej. Osoby takie uważają, że potrzebne jest im nie tylko zabezpieczenie egzystencjalne w postaci renty i innych świadczeń z tytułu niemożności lub ograniczenia podjęcia pracy, ale sam fakt wystąpienia obciążenia jest powodem do jego rekompensowania środkami przede wszystkim pieniężnymi. Postawa roszczeniowa przejawia się nie tylko w odwoływaniu do funkcji opiekuńczej organów państwowych i samorządowych, ale do całego społeczeństwa i wszystkich jego instytucji. Taką postawę przyjmują wobec Kościoła, w tym wobec parafii, 
co sprawia, że osoby z niepełną sprawnością postrzegają siebie przede wszystkim jako adresatów działalności innych wierzących i społeczeństwa, a w niewielkim stopniu jako podmiotów zaangażowania w życie społeczności.

Pogłębianie treści wiary i umacnianie postaw religijnych - konieczne katolikom w Polsce - w odniesieniu do osób z niepełną sprawnością w parafii ma także swoją specyfikę. Ze względu na cechy niepełnosprawności ludzie nią dotknięci nie zawsze mogą w pełni korzystać z przepowiadania w ramach duszpasterstwa zwyczajnego w parafii, dlatego głoszenie im Dobrej Nowiny ma w znacznym stopniu charakter zindywidualizowany. Dotyczy to w pierwszej kolejności ludzi niesłyszących, dla których konieczna jest pomoc osób posługujących się językiem migowym lub zainstalowanie w kościele odpowiednich urządzeń elektronicznych, umożliwiających przekaz w tym języku. Wobec faktu, że osoby znające język migowy, jak również urządzenia takie nie zawsze i nie wszędzie są dostępne, osoby niesłyszące lub niedosłyszące napotykają na znaczne trudności w korzystaniu z dostępnych innym form duszpasterstwa zwyczajnego w tym zakresie. Ważna jest więc formacja ogółu parafian do pomocy takim osobom. Chodzi tu między innymi o umożliwienie niedosłyszącym zajmowanie miejsc w pobliżu głośników czy niesłyszącym czytającym z ruchu warg - takich miejsc, z których możliwe jest wyraźne widzenie celebransa, lektorów, psałterzystów itp..

$\mathrm{Na}$ ograniczenia w słuchaniu słowa Bożego napotykają także osoby z niepełnosprawnością ruchową, intelektualną, słabowidzące i niewidome. Ograniczenia te wynikają w znacznym stopniu z trudności komunikacyjnych, utrudniających dotarcie do kościoła i innych miejsc przepowiadania. W przypadku osób z uszkodzonym wzrokiem ograniczenia dotyczą korzystania w wizualnych form przepowiadania takich, jak słowo pisane i drukowane, multimedia czy media społecznościowe. Mimo rozwijanych środków transportu i mediów elektronicznych, ułatwiających osobom z niepełnosprawnością komunikację z otoczeniem, nadal

9 Por. K. Półtorak, Przepowiadanie słowa Bożego osobom niesłyszacym, w: Katecheza specjalna dzisiaj. Problemy i wyzwania, red. J. Stala, Kielce 2003, s. 388-394. 
mają one trudniejszy dostęp do Dobrej Nowiny niż pozostali członkowie parafii ${ }^{10}$.

Budowanie parafii jako wspólnoty wiary z osobami z niepełnosprawnością jest możliwe wówczas, gdy uczestniczą one jako podmioty głoszenia słowa Bożego. Zwraca się uwagę na możliwość sprawowania przez nie posługi lektora, psałterzysty czy kantora w zgromadzeniu liturgicznym. Dostępna jest dla nich także działalność katechetyczna, zgodna z rodzajem i stopniem niepełnosprawności. Oprócz urzędowej działalności w ramach posługi słowa $\mathrm{w}$ parafii konieczne jest zaangażowanie osób z niepełną sprawnością na sposób apostolski. Chodzi tu zarówno o świadectwo słowa, jak i zaangażowanie takich osób w zrzeszenia religijne mające za cel propagowanie Dobrej Nowiny. Świadectwo słowa osób z niepełnosprawnością jest bardziej wyraziste, a przez to bardziej przekonujące niż to dawane przez osoby zdrowe i sprawne. Ma to znaczenie zwłaszcza dla ludzi przeżywających trudności i przeciwności życiowe. Osoby takie nierzadko obwiniają innych ludzi za swoje cierpienie, a coraz częściej także kierują pretensje do Boga. Świadectwo słowa ludzi obarczonych niepełną sprawnością pomaga bardziej racjonalnie ocenić trudności życiowe, a przede wszystkim ich przyczyny, i znaleźć sposoby poprawy sytuacji ${ }^{11}$.

Uczestnictwo osób z niepełną sprawnością w kołach biblijnych lub $\mathrm{w}$ podobnych małych grupach religijnych pozwala pogłębiać formację intelektualną i apostolską. Małe grupy mogą zaspokoić potrzebę przynależności i oparcia duchowego, są miejscem refleksji i wymiany doświadczeń związanych z przeżywaną wiarą w warunkach niepełnej sprawności. Umożliwiają także wymianę doświadczeń związanych ze świadectwem słowa i umacnianiem postawy apostolskiej ${ }^{12}$.

10 Por. M. Kowalczyk, Priorytety $w$ działalności charytatywnej na rzecz osób niepełnosprawnych ruchowo w stopniu znacznym, w: Przestrzenie pracy socjalnej, red. J. Stala, Tarnów 2010, s. 289-290.

11 Por. D. Lipiec, Duszpasterstwo niepełnosprawnych w parafii, „Perspectiva” 8 (2009) nr 2, s. $112-113$.

12 Por. B. Biela, Wspótpraca świeckich z hierarchią w parafii w świetle współczesnego nauczania Kościoła, w: Dei enim sumus adiutores. Opuscula Adamo Przybecki septuagenario dedicata, Poznań 2019, s. 243-264. 
Budowanie parafii-wspólnoty wiary z osobami dotkniętymi niepełną sprawnością wymaga formacji ludzi sprawnych do współpracy z nimi. Mimo działalności organów rządowych, samorządowych i różnorakich organizacji trzeciego sektora, wiedza dotycząca specyfiki życia osób z niepełną sprawnością jest niewystarczająca u ogółu społeczeństwa, aby sprawni mogli efektywnie z nimi współpracować. Pogłębianie tej świadomości jest jednym z celów duszpasterstwa parafialnego i apostolatu bardziej świadomych świeckich. Znajomość specyfiki niepełnosprawności, jej rodzajów, stopni, skutków itp. oraz osób dotkniętych nią w parafii jest warunkiem efektywnej współpracy w apostołowaniu razem z nimi. Chodzi o współpracę na zasadach partnerskich, w której osoby z niepełną sprawnością dźwigają własną część odpowiedzialności za dzieło głoszenia Dobrej Nowiny. Świadomość możliwości osób z niepełnosprawnością w tym zakresie chroni je przed deprecjonowaniem oraz nadmiernym lub nieprawidłowym angażowaniem $\mathrm{w}$ apostolstwo ${ }^{13}$.

\section{Budowanie parafii-wspólnoty kultu}

Budowanie parafii jako wspólnoty kultu odbywa się przez sprawowanie i przyjmowanie sakramentów, celebrowanie nabożeństw oraz modlitwę chrześcijańską. W centrum życia poszczególnych wierzących oraz ich wspólnoty znajduje się Eucharystia. Do niej zmierza całe życie chrześcijańskie i z niej bierze ono swój początek. Eucharystia ześrodkowuje zarówno życie duchowe wiernych, jak i całą ich egzystencję. Jej celebrowanie jest szczytem życia wspólnoty katolickiej, jest ono także źródłem tej wspólnoty ${ }^{14}$.

To, co odnosi się do ogółu wierzących i budowania przez nich wspólnoty parafialnej, ma zastosowanie także do osób z niepełną sprawnością i ich uczestnictwa we wspólnocie wierzących. Ich podmiotowość wynikająca z godności osoby ludzkiej oraz faktu bycia dzieckiem Bożym jest

13 Por. A. Krause, Współczesne tendencje $w$ procesie rewalidacji osób niepełnosprawnych normalizacja, w: Katecheza specjalna dzisiaj. Problemy $i$ wyzwania, red. J. Stala, Kielce 2003, s. 297-307.

14 R. Kamiński, Duszpasterstwo w społeczeństwie pluralistycznym, dz. cyt., s. 161-177. 
podstawą do pełnego uczestnictwa w komunii wierzących. Budowanie wspólnoty eucharystycznej z ludźmi z niepełną sprawnością ma początek w ich formacji do pełnego uczestnictwa w Eucharystii. Dalsze przygotowanie odbywa się w domu rodzinnym, gdy rodzice zabierają ze sobą dziecko na Mszę Świętą lub nabożeństwo eucharystyczne. W sposób spontaniczny dokonuje się socjalizacja religijna dziecka. Oswaja się ono z miejscem kultu, uczy się w nim funkcjonować, przede wszystkim jednak dokonuje się jego inicjacja religijna i następuje pogłębienie jego więzi z Bogiem i świętymi. Przebieg tego procesu uzależniony jest od rodzaju i stopnia niepełnosprawności dziecka, a także od stosunku rodziców do niego i jego niepełnej sprawności. Mimo licznych kampanii społecznych, nadal wielu rodziców nie akceptuje kondycji swojego potomstwa lub jego samego, uważając jego obecność w rodzinie i wychowanie jako porażkę lub niepowodzenie życiowe. Wpływ na socjalizację religijną w rodzinie ma także rodzaj niepełnosprawności dziecka i jej stopień. Specyfika ograniczeń wynikających z obciążenia wpływa na sposób przebywania dziecka w kościele i uczenie go uczestnictwa w liturgii i nabożeństwach. Również stopień niepełnosprawności ma wpływ na ten proces. Im jest on głębszy, tym trudniej jest przygotować dziecko do pełnego uczestnictwa we Mszy Świętej. Należy również zauważyć, że niektóre dzieci nigdy nie osiągają takiej możności.

Taka formacja religijna dokonuje się $\mathrm{w}$ wielu wypadkach poza rodzinną parafią dziecka z niepełną sprawnością. Część dzieci przebywa w specjalnych ośrodkach szkolno-wychowawczych, zamieszkując w internatach. W zależności od profilu ośrodka - katolicki lub nie, a także od osób w nim zatrudnionych, uczniowie nie zawsze mają możliwość uczestniczenia w Eucharystii.

W zależności od tego, czy dziecko przebywa w ośrodku szkolno-wychowawczym, czy uczęszcza do szkoły masowej z oddziałami integracyjnymi, jego przygotowanie bliższe do Pierwszej Komunii Świętej i spowiedzi odbywa się na terenie ośrodka lub w jego rodzinnej parafii. Ten etap przygotowania obejmuje formacje intelektualną i naukę przystępowania do Komunii Świętej oraz spowiadania się. Ostatni etap przygotowania, który można określić jako przygotowanie bezpośrednie, odbywa się w parafii, w której dziecko przystępuje po raz pierwszy do tych sakramentów. 
Należy zauważyć, że parafia, w której dziecko z niepełną sprawnością po raz pierwszy przystępuję do spowiedzi i Komunii Świętej nie zawsze jest jego rodzinną parafią. Pewien odsetek dzieci, przebywających w specjalnych ośrodkach, przeżywa tę uroczystość wraz z innymi dziećmi ze swojej grupy. Również część dzieci uczących się w szkołach masowych przystępuje do tych sakramentów po raz pierwszy w parafii, na terenie której znajduje się szkoła wraz z innymi dziećmi z klasy. Z nimi czują się pewnie i bezpiecznie. Pewien odsetek rodziców posyła swoje dzieci do Pierwszej Komunii Świętej i spowiedzi w rodzinnej parafii. Ich motywacja bywa różna, często przeważają względy natury praktycznej. Nie zawsze kierują się oni kryteriami teologicznymi ${ }^{15}$.

Budowanie wspólnoty eucharystycznej z ludźmi z niepełną sprawnością zawiera w sobie elementy integracji. Chodzi tu o umożliwienie takim osobom dotarcie do kościoła, poruszanie się w nim, zajmowanie miejsca, powrót do domu. Wiąże się to z szeroko nagłaśnianym problemem likwidowania barier architektonicznych i pomocy takim osobom w komunikacji. Niektóre działania wymuszają niejako przepisy państwowe, zwłaszcza zmierzające do ułatwiania poruszania się ludziom z niepełnosprawnością ruchową. Do pełnego uczestnictwa w Eucharystii i swobodnego przystępowania do Komunii św. konieczne jest podejmowanie wielu różnorakich inicjatyw ze strony duszpasterzy i parafian. Wśród nich na czoło należy wysunąć formację parafian do pomocy takim osobom w podchodzeniu do Komunii św., powrotu na poprzednie miejsce oraz do udzielenia im wszelkiej koniecznej pomocy związanej z dotarciem do kościoła, przebywania w nim, wykonywaniu aktów kultu i powrotu do domu.

Budowanie autentycznej wspólnoty eucharystycznej z osobami z niepełną sprawnością jest możliwe wtedy, gdy są one w niej podmiotowo zaangażowane. Współcześnie dostępne jest dla takich osób wykonywanie wielu posług w liturgii, takich jak: lektora, akolity, ministranta, kantora czy psałterzysty. Możliwe jest także wstępowanie takich osób do chórów

15 Por. K. Sosna, Przygotowanie do Komunii Świętej osób niepełnosprawnych w świetle dekretu "Quam singulari”, w: Eucharystia - pokuta i pojednanie w katechezie. Problemy i wyzwania, red. J. Stala, Kielce 2007, s. 241-244. 
i scholi. Ograniczeniem w zaangażowanie się w taką aktywność jest stopień zrehabilitowania, czyli rzeczywista możliwość wykonywania czynności liturgicznych przez poszczególne osoby. W wykonywaniu przez nie posług w liturgii potrzebna jest także pomoc osób sprawnych, ponieważ w wielu przypadkach - mimo zrehabilitowania - osoby z niepełną sprawnością nie mogą samodzielnie wykonywać niektórych czynności. Związane jest to najczęściej z lokalnymi uwarunkowaniami, takimi jak architektura konkretnego kościoła czy określone miejscowe zwyczaje.

Osoby z niepełną sprawnością uczestniczą w budowaniu parafii jako wspólnoty kultu także poprzez przyjmowanie innych sakramentów. Dużą rolę odgrywa przystępowanie do sakramentu pokuty i pojednania. Ma on duże znaczenie dla pogłębiania osobistych więzi z Bogiem oraz ze wspólnotą. Praktykowanie tego sakramentu przez ludzi cierpiących ma wymiar wyrazistego apostolatu wobec pozostałych członków parafii. Osoby z niepełną sprawnością dają bowiem świadectwo przekraczania własnych słabości i ograniczeń w sferze duchowej, moralnej, popierając je wysiłkiem w sferze fizycznej i psychicznej. Ich świadectwo służy odnowie i umacnianiu wspólnoty parafialnej. Także przystępowanie do innych sakramentów, w sposób im właściwy i dostępny dla ludzi z niepełną sprawnością, przyczynia się do rozwoju wspólnoty wierzących.

Budowanie wspólnoty modlitewnej z osobami z niepełną sprawnością dokonuje się przez włączenie ich w modlitwę parafialną. Jako członkowie parafii osoby takie włączone są na mocy chrztu w komunię modlitewną Kościoła. Ich modlitwa jest częścią „skarbca” modlitewnego tworzonego przez Kościół, w tym ich parafię. Jednakże poprzez duszpasterstwo i apostolstwo w parafii osoby z niepełną sprawnością włączane są w apostolstwo modlitwy. One same i wskazane przez nie intencje stają się przedmiotem modlitwy całej parafii. Przez to cała wspólnota parafialna okazuje im chrześcijańską miłość i wspiera je jako swoich członków. Podobnie osoby z niepełnosprawnością włączane są na sposób podmiotowy w apostolstwo modlitwy. Przez wiele osób ludzie z niepełną sprawnością postrzegani są jako bliżsi Bogu przez cierpienie, które jest ich udziałem. Wiele z nich faktycznie prowadzi pogłębione życie duchowe, łącząc własne cierpienie z cierpieniem Chrystusa na krzyżu. Łączą oni cierpienie z modlitwą zanoszoną w intencji całej parafii i poszczególnych jej 
członków, budując w wyjątkowy sposób wspólnotę modlitewną i dając przez to świadectwo wobec zdrowych i sprawnych.

\section{Budowanie parafii-wspólnoty miłości braterskiej}

Miłość braterska jest okazywana na wiele sposobów. Katolicy świeccy wyrażają ją przede wszystkim przez chrześcijański styl życia. Mogą ją także praktykować prowadząc działalność charytatywną, spontanicznie lub w sposób zorganizowany. Budowanie wspólnoty miłości możliwe jest dzięki zaangażowaniu laikatu w działalność rad parafialnych oraz zrzeszeń religijnych istniejących w parafii ${ }^{16}$. Wszystkie te sposoby dostępne są dla osób z niepełną sprawnością, w zależności od rodzaju i stopnia niepełnosprawności.

Chrześcijański styl życia osób z niepełną sprawnością ma swoją specyfikę wynikającą z faktu bycia taką osobą. Przez sakrament chrztu i bierzmowania ludzie dotknięci niepełnosprawnością powołani są - na równi z ludźmi sprawnymi - do realizacji powołania i posłannictwa chrześcijańskiego. Jednakże ubytki w sferze fizycznej lub psychicznej modyfikują ich funkcjonowanie w Kościele i świecie, dlatego ich styl życia jest odmienny od innych katolików. W sposób sobie właściwy i na miarę możliwości realizują oni apostolat rodzinny, zgodnie ze stanem życia. Jako dziecko, małżonek lub rodzic budują oni wspólnotę rodzinną. Wspólnota ta ze swej strony przyczynia się do budowania parafii rozumianej jako rodzina rodzin. W podobny sposób osoby z niepełną sprawnością budują rodzinę wielką, kształtując z niej wspólnotę osób powiązanych ze sobą więzami pokrewieństwa ${ }^{17}$.

Chrześcijański styl życia katolików z niepełną sprawnością przyczynia się do budowania wspólnoty sąsiedzkiej. Pomoc sąsiedzka, życie towarzyskie prowadzone $\mathrm{w}$ ramach środowiska zamieszkania przyczyniają się do pogłębiania więzi między ludźmi przebywającymi blisko siebie. s. $155-158$.

R. Kamiński, Działalność zbawcza Kościoła $w$ teorii i praktyce pastoralnej, dz. cyt.,

17 Por. D. Lipiec, Formacja chrześcijańska niepełnosprawnych w rodzinie, „Studia Pastoralne” 11 (2015), s. 153-164. 
Pomoc osób z niepełnosprawnością, mając realnie nawet takie samo znaczenie jak wsparcie osób sprawnych, ma jednak większą wartość apostolską dzięki większemu wysiłkowi, a więc także i ofierze, jaką muszą ponieść osoby z obciążeniami ${ }^{18}$.

Działalność charytatywna osób z niepełną sprawnością, podobnie jak pozostałych katolików, realizowana jest w sposób spontaniczny i zorganizowany. Spontanicznie osoby takie składają ofiary na rzecz osób potrzebujących w Polsce i zagranicą lub wykonują określone dzieła na ich korzyść. Dużą wartość apostolską ma udzielanie wsparcia materialnego i duchowego przez ludzi z niepełną sprawnością, zwłaszcza w środowisku życia, chociaż przekonującym świadectwem jest także świadczenie pomocy osobom nieznanym, znajdującym się w znacznym oddaleniu ${ }^{19}$.

Osoby z niepełną sprawnością mogą być członkami parafialnych zespołów Caritas i innych zespołów charytatywnych. W ten sposób mogą podmiotowo brać udział w zorganizowanej posłudze charytatywnej Kościoła. Dostępna jest dla nich działalność organizacyjna, pozyskiwanie środków i rozdzielanie dóbr potrzebującym. Odpowiedzialni za działalność charytatywną w parafii, przede wszystkim proboszczowie, powinni mieć świadomość, że znaczy odsetek ludzi z niepełną sprawnością uzyskuje niskie dochody, co sprawia, że ludzie ci są w pierwszej kolejności adresatami posługi charytatywnej wspólnoty parafialnej.

Budowanie wspólnoty parafialnej z osobami z niepełną sprawnością wiąże się $\mathrm{z}$ angażowaniem ich $\mathrm{w}$ zrzeszenia religijne. Różnego rodzaju stowarzyszenia, ruchy religijne i małe grupy dają możliwość, by do ich wspólnot wstępowali ludzie z niepełnosprawnością ruchową, sensoryczną i intelektualną. Taką otwartośc przyjęcia oferują zarówno zrzeszenia o charyzmacie formacyjnym, w tym modlitewnym, jak i czynnym, apostolskim. Angażując takie osoby, bierze się pod uwagę specyfikę ograniczeń wynikających z niepełnosprawności. Należy zauważyć, że osoby

18 Por. J. Wal, Apostolat środowiskowy chrześcijan, w: Teologia pastoralna, t. 2, red. R. Kamiński, Lublin 2002, s. 565-574.

19 Por. W. Przygoda, Budowanie komunii Kościoła dzięki świadectwu miłości w świetle motu proprio „Intima Ecclesiae natura”, w: Kościót - komunia i dialog. Księga pamiątkowa ofiarowana księdzu biskupowi Kazimierzowi Ryczanowi w 75. rocznicę urodzin, red. P. Kantyka, J. Czerkawski, T. Siemieniec, Kielce 2014, s. 327-331. 
takie wraz z obecnością wnoszą $\mathrm{w}$ dynamikę grupową szczególny walor świadectwa, trudny do dawania przez ludzi w pełni sprawnych ${ }^{20}$.

W dobie integracji społecznej osób z niepełną sprawnością, jak również ich integracji eklezjalnej, ludzie ci chętnie podejmują się realizacji ról społecznych na równi z ludźmi w pełni sprawnymi. Coraz bardziej unikają oni podkreślania swej niesprawności. Jest to zauważalne w duszpasterstwie takich osób, które coraz rzadziej uczestniczą w pracach duszpasterstwa nadzwyczajnego, im dedykowanego. Dotyczy to duszpasterstwa na płaszczyźnie diecezjalnej i parafialnej. Mimo to istnieje potrzeba podejmowania inicjatyw duszpasterskich w parafii adresowanych do osób z niepełną sprawnością i ich rodzin. Wynika to z faktu, że mimo znacznego w wielu wypadkach stopnia zrehabilitowania i integracji społecznej, nie wszystkie ich potrzeby religijne są zaspokajane w ramach duszpasterstwa zwyczajnego, adresowanego do ogółu wierzących. Konieczne jest podejmowanie takich inicjatyw pastoralnych, które zmierzają do zaspokojenia specyficznych potrzeb konkretnych osób z niepełnosprawnością zamieszkałych w parafii. Osoby te mogą być objęte opieką w małych grupach lub przez formy duszpasterstwa indywidualnego. Również angażowanie ludzi z niepełną sprawnością w życie wspólnoty parafialnej na sposób podmiotowy wymaga indywidualnego podejścia i oceny ich predyspozycji i potrzeb.

\section{Zakończenie}

Osoby z niepełną sprawnością uczestniczą w budowaniu wspólnoty parafialnej poprzez słuchanie słowa Bożego, uczestnictwo w liturgii i przyjmowanie sakramentów, modlitwę oraz praktykowanie miłości chrześcijańskiej. Jednocześnie na mocy chrztu i bierzmowania powołane są do czynnego uczestnictwa w budowaniu tej wspólnoty i w jej życiu. Swoje powołanie i posłannictwo mogą one realizować w sposób, w jaki umożliwia im to przekraczanie barier wynikających z ograniczonej sprawności. W budowaniu parafii-wspólnoty osoby z niepełną sprawnością

20 Por. R. Kamiński, Zrzeszenia religijne a parafia, w: $W$ prostocie prawdy, w pokorze miłości, red. T. Borutka, A. Baczyński, M. Ostrowski, Kraków 2008, s. 289-292. 
potrzebują pomocy innych członków zgromadzenia. W pierwszej kolejności jest to wsparcie okazywane przez duszpasterzy, którzy kierują je bezpośrednio do nich, a także formują ogół parafian do pomocy potrzebującym. Wsparcie to jest konieczne także ze strony wszystkich członków parafii, dla których udzielanie go wynika z nakazu misyjnego Chrystusa.

\section{Bibliografia}

Bartoszek A., Niepetnosprawność osób jako wyzwanie moralne, w: Osoby niepełnosprawne w życiu społeczeństwa i Kościoła, red. A. Bartoszek, D. Sitko, Tarnów 2003, s. 63-90.

Biela B., Wspótpraca świeckich z hierarchia w parafii w świetle wspótczesnego nauczania Kościoła, w: Dei enim sumus adiutores. Opuscula Adamo Przybecki septuagenario dedicata, Poznań 2019, s. 243-264.

Cynarzewska-Wlaźlik L., Wspólnota. W naukach społecznych, w: Encyklopedia katolicka, t. 20, red. E. Gigilewicz, Lublin 2014, kol. 1001-1002.

Kamiński R., Duszpasterstwo w społeczeństwie pluralistycznym, Lublin 1997.

Kamiński R., Działalność zbawcza Kościoła w teorii i praktyce pastoralnej, Lublin 2007.

Kamiński R., Zrzeszenia religijne a parafia, w: W prostocie prawdy, w pokorze miłości, red. T. Borutka, A. Baczyński, M. Ostrowski, Kraków 2008, s. 281-292.

Kodeks prawa kanonicznego, Poznań 1984.

Kowalczyk M., Priorytety w działalności charytatywnej na rzecz osób niepetnosprawnych ruchowo w stopniu znacznym, w: Przestrzenie pracy socjalnej, red. J. Stala, Tarnów 2010, s. 285-302.

Krause A., Wspótczesnetendencje w procesie rewalidacjiosóbniepetnosprawnych-normalizacja, w:Katechezaspecjalna dzisiaj.Problemy iwyzwania, red.J.Stala, Kielce 2003, s.297-316.

Lipiec D., Duszpasterstwo niepetnosprawnych w parafii, „Perspectiva” 8 (2009) nr 2, s. 107-124.

Lipiec D., Formacja chrześcijańska niepełnosprawnych w rodzinie, „Studia Pastoralne” 11 (2015), s. 153-164.

Nadbrzeżny A., Wspólnota. W teologii, w: Encyklopedia katolicka, t. 20, red. E. Gigilewicz, Lublin 2014, kol. 1000-1001.

Półtorak K., Przepowiadanie słowa Bożego osobom niesłyszacym, w: Katecheza specjalna dzisiaj. Problemy i wyzwania, red. J. Stala, Kielce 2003, s. 375-410.

Przygoda W., Budowanie komunii Kościoła dzięki świadectwu miłości w świetle motu proprio „Intima Ecclesiae natura”, w: Kościół - komunia i dialog. Księga pamiątkowa ofiarowana księdzu biskupowi Kazimierzowi Ryczanowi w 75. rocznicę urodzin, red. P. Kantyka, J. Czerkawski, T. Siemieniec, Kielce 2014, s. 327-338.

Sosna K., Przygotowanie do Komunii Świętej osób niepetnosprawnych w świetle dekretu "Quam singulari", w: Eucharystia - pokuta i pojednanie w katechezie. Problemy $i$ wyzwania, red. J. Stala, Kielce 2007, s. 235-244.

Wal J., Apostolat środowiskowy chrześcijan, w: Teologia pastoralna, t. 2, red. R. Kamiński, Lublin 2002, s. 562-578. 